\title{
Bernard Guenée, Du Guesclin et Froissart. La fabrication de la renommée
}

\section{G. Matteo Roccati}

\section{(2) OpenEdition}

10 Journals

\section{Édition électronique}

URL : http://journals.openedition.org/studifrancesi/5535

DOI : 10.4000/studifrancesi.5535

ISSN : 2427-5856

Éditeur

Rosenberg \& Sellier

\section{Édition imprimée}

Date de publication : 1 septembre 2011

Pagination : 386

ISSN : 0039-2944

\section{Référence électronique}

G. Matteo Roccati, «Bernard Guenée, Du Guesclin et Froissart. La fabrication de la renommée », Studi Francesi [En ligne], 164 (LV | II) | 2011, mis en ligne le 30 novembre 2015, consulté le 11 janvier 2021. URL : http://journals.openedition.org/studifrancesi/5535; DOI : https://doi.org/10.4000/studifrancesi. 5535

Ce document a été généré automatiquement le 11 janvier 2021.

\section{(c)}

Studi Francesi è distribuita con Licenza Creative Commons Attribuzione - Non commerciale - Non opere derivate 4.0 Internazionale. 


\title{
Bernard Guenée, Du Guesclin et Froissart. La fabrication de la renommée
}

\author{
G. Matteo Roccati
}

\section{RÉFÉRENCE}

BERNARD GUENÉE, Du Guesclin et Froissart. La fabrication de la renommée, Paris,

Tallandier, 2008, $238 \mathrm{pp}$.

1 L'ouvrage s'attache d'abord à expliciter, depuis l'Antiquité jusqu'au $\mathrm{Xv}^{\mathrm{e}}$ siècle, la conception de la renommée et ses liens avec la naissance, le mérite, la mémoire, ainsi qu'à définir les personnages susceptibles de l'acquérir: les chevaliers par leur vaillance, les clercs par leur science. Le réseau institutionnel de l'Eglise permettait toutefois à ces derniers de s'affranchir de la hiérarchisation sociale; une naissance illustre était par contre indispensable aux premiers pour échapper à l'anonymat. Cette situation se modifie au cours du Moyen Âge: l'importance prise par l'opinion publique au sein de la société politique permet à des personnes qui auparavant en étaient exclues d'accéder à la renommée, tel Bertrand du Guesclin au XIV siècle. Cet homme de guerre de petite noblesse sort de l'obscurité pour devenir le $X^{e}$ preu, grâce à sa vaillance, mais surtout à son habileté à se servir des médias de l'époque pour s'imposer dans l'opinion.

2 L'A. retrace ensuite, entre le $\mathrm{XII}^{\mathrm{e}}$ et le $\mathrm{xIV}^{\mathrm{e}}$ siècle, le cheminement des historiens, «artisans de la renommée» (p. 103). L'étude de la manière dont ils conçoivent leur travail, le statut de leur discipline, leur public, et l'étude de la diffusion des œuvres et de l'évolution de ses canaux permettent de suivre la mise en place de la situation moderne: Froissart se sert de son art pour accéder lui-même à la renommée. 